Jurnal

Kardiologi Indonesia

J Kardiol Indones. 2015;36:46-5 I

ISSN $0126 / 3773$

\title{
Optimization of Hypertension Treatment using Fixed-Dose Combination of Perindropril/Amlodipine
}

\author{
Evan Hindoro, Arlis Karlina
}

Department of Cardiology and Vascular Medicine, Faculty of Medicine, Universitas Indonesia, Jakarta
A lot of hypertensive patients require two or more antihypertensive drugs to control and maintain normal blood pressure. Combination of antihypertension is recommended either as first or second line treatment. Among available antihypertension medications, combination of reninangiotensinaldosteron (RAAS) inhibitor with calcium channel blocker or diuretics are more recommended as they have sinergistic clinical and biomolecular effects.

Furthermore, single pill dosage is associated with higher patients compliants and lower faults incidence in medication. Severeal fixed-dose combinations are currently available in the market to give easier hypertension control and patients compliants. This short review focus on combination of perindropril and amlodipine.

(J Kardiol Indones. 20I5;36:46-5I)

Keywords: antihypertension, fixed-dose combination 


\title{
Optimalisasi Pengobatan Tekanan Darah dengan Fixed-Dose Combination Perindopril/Amlodipine
}

\author{
Evan Hindoro, Arlis Karlina
}

\begin{abstract}
Banyak pasien yang memerlukan 2 atau lebih obat anti-hipertensi untuk menjaga tekanan darah agar terkontrol. Oleh karena itu, terapi kombinasi dapat merupakan terapi lini pertama atau kedua anti hipertensi. Panduan tatalaksana hipertensi telah menetapkan bahwa strategi memilih kombinasi penghambat sistem renin-angiotensinaldosteron $(R A A S)$ dengan penghambat kanal kalsium $(C C B)$ atau diuretic harus lebih diutamakan agar memaksimalkan cara kerja dan jalur molekuler mereka yang sinergis.

Selanjutnya formulasi pil tunggal (single pill) yang diyakini akan meningkatkan kepatuhan minum obat dan menurunkan kejadian kesalahan dalam pengobatan. Oleh karena itu saat ini banyak tersedia antihipertensi dengan fixed dose combination yaitu pil tunggal yang berisi kombinasi 2 jenis obat. Tulisan ini membahas kombinasi perindropril dan amlodipin sebagai sebuah fixed dose combination.
\end{abstract}

(J Kardiol Indones. 2015;36:46-51)

Kata kunci: antihipertensi, fixed dose combination

M eskipun pemahaman dan kesadaran tentang peranan hipertensi pada penyakit kardiovaskuler terus - menerus meningkat, World Health Organization (WHO) membuat hipertensi sebagai faktor resiko mortalitas nomer 1 dengan 13\% kematian di dunia yang disebabkan oleh penyakit yang berhubungan dengan hipertensi. ${ }^{1}$ Tentunya, pasien dengan hipertensi tidak terkontrol akan rutin ditemukan pada praktek kedokteran sehari-hari dan akan terus menjadi tantangan bagi banyak dokter.

\section{Alamat Korespondensi}

dr. Alis Karlina

Email: aliskarlina@gmail.com
Sekarang banyak diketahui bahwa banyak pasien yang memerlukan 2 atau lebih obat anti-hipertensi untuk mencapai dan menjaga tekanan darah agar terkontrol. ${ }^{2}$ Oleh karena itu, terapi kombinasi telah didukung sepenuhnya oleh pedoman sebagai lini pertama dan lini kedua terapi alternatif. Belakangan ini, pedoman telah menetapkan bahwa strategi dengan memilih kombinasi penghambat sistem reninangiotensin-aldosteron ( $R A A S)$ dengan penghambat kanal kalsium $(C C B)$ atau diuretik harus lebih diutamakan agar memaksimalkan cara kerja dan jalur molekuler mereka yang sinergis atau sejalan. ${ }^{3}$ Khususnya, kombinasi penghambat Angiotension Converting Enzyme (ACE) seperti perindopril, dengan CCB dihidropiridin seperti amlodipine, diharapkan memberikan perbaikan tekanan darah dan luaran kardiovaskuler, sembari meningkatkan 
aliran vena dan menurunkan kejadian oedema pada pengobatan amlodipine. ${ }^{4,5}$ Selanjutnya, pedoman telah mendukung formulasi pil tunggal (Single pill) yang diyakini akan meningkatkan kepatuhan minum obat dan menurunkan kejadian kesalahan dalam pengobatan. ${ }^{3}$

Pengobatan hipertensi dengan perindopril/ amlodipine belakangan ini diakui dengan bentuk Fixed-Dose Combination (FDC), sesuai dengan rekomendasi pedoman dan didukung dengan hasil studi ASCOT (Anglo-Scandinavian Cardiac Outcome
Trial) dan dengan data tambahan yang menjelaskan setiap obat sebagai monoterapi. ${ }^{3-6}$ Pada studi ASCOT, pengobatan pada pasien hipertensi dengan kombinasi CCB (amlodipine) dan penghambat ACE (perindopril) dengan jelas menurunkan mortalitas dan kejadian kardiovaskuler dibandingkan dengan pengobatan dengan penyekat reseptor betaadrenergik atau strategi dengan diuretik tiazid. ${ }^{7}$ Selanjutnya, amlodipine, yang mana juga digunakan untuk mengurangi nyeri dada pada pasien penyakit arteri koroner, telah menunjukkan penurunan
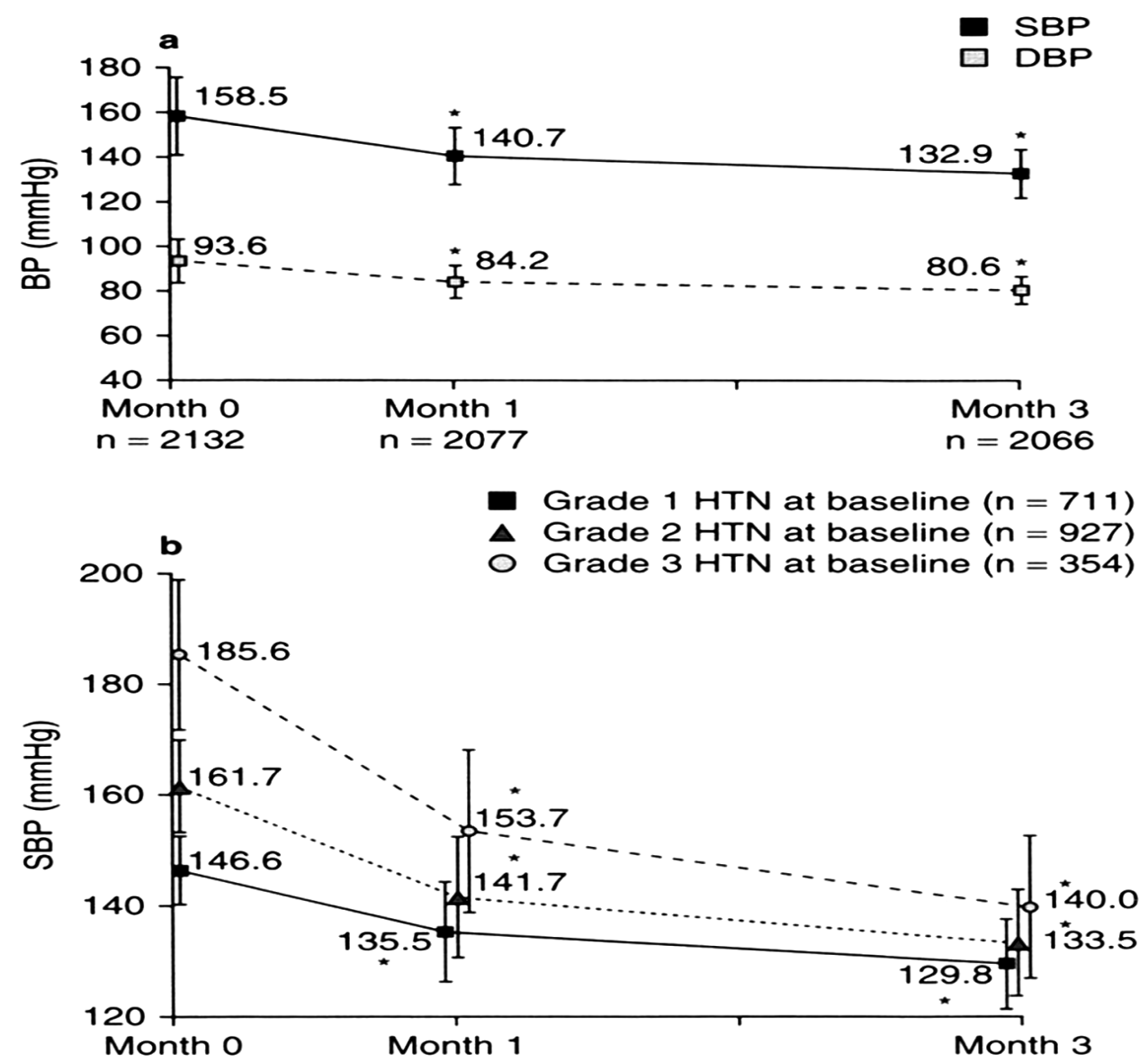

Gambar 1. Tekanan darah setelah 1 bulan dan 3 bulan pengobatan dengan perindopril/ amlodipine. (a) TDS dam TDD pada seluruh kohort; (b) TDS dinyatakan dengan tingkat dari hipertensi. Terdapat tiga tingkatan hipertensi menurut definisi pedoman hipertensi ESC/ ESH 2007. ${ }^{[2]}$ Mean dan standar deviasi dilaporkan; analisis dilakukan pada populasi yang ditujukan untuk diobati. Pada figur 1a jumlah pasien terhadap TDS digambarkan pada aksis $\mathrm{x}$; jumlah pasien terhadap TDD sama \pm 5 pasien. Angka pada figur $1 \mathrm{~b}$ sesuai dengan jumlah pasien pada setiap subgroup pada baseline. $\mathrm{BP}=$ Blood pressure; $\mathrm{DBP}=$ Diastolic BP; $\mathrm{HTN}$ $=$ Hypertension $\mathrm{SBP}=$ Systolic $B P .{ }^{*} \mathrm{p}<0,0001$ vs baseline. 
tekanan darah dan kejadian kardiovaskuler pada pasien hipertensi dengan atau tidak adanya penyakit arteri koroner. ${ }^{8-11}$ Perindopril telah menunjukkan penurunan tekanan darah secara efektif, memperbaiki fungsi endotel dan abnormalitas dari struktur dan fungsi pembuluh darah yang berkaitan dengan hipertensi untuk memperlambat aterosklerosis dan mortalitas kardiovaskuler secara signifikan pada banyak pasien.

Pengobatan dengan fixed-dose combination menggunakan penghambat Angiotension-Converting Enzyme (ACE), seperti perindopril ditambah dengan penghambat kanal kalsium (CCB), seperti amlodipine, telah didukung oleh pedoman karena mereka memperbaiki kontrol tekanan darah dan luaran kardiovaskuler pada pasien hipertensi, sementara itu juga dapat ditoleransi dan ditaati dengan baik oleh pasien.

Berdasarkan Studi SYMBIO (StudY of optiMized Blood pressure lowering therapy with fixed cOmbination perindopril/amlodipine), studi ini untuk mengetahui kenyataan pada praktek klinis pada efek penurunan tekanan darah dan toleransi perindopril/amlodipine FDC pada pasien yang pernah diobati dengan penghambat ACE dan/atau CCB namun hipertensinya tidak terkontrol dan pada hipertensi yang terkontrol namun tidak toleran pada pengobatan penghambat ACE dan/atau CCB yang sebelumnya, dokter internis dan dokter umum di Slovakia diminta untuk mempertimbangkan pendaftaran pada pasien hipertensi yang diobati dengan penghambat ACE dan/atau CCB (terutama amlodipine) untuk hipertensi dan yang telah diobati dengan perindopril/amlodipine FDC oleh dokter. Pasien tersebut adalah pasien yang memiliki hipertensi yang tidak terkontrol secara adekuat (TDS/ $\mathrm{TDD} \geq 140 / 90$ atau $\geq 130 / 80 \mathrm{mmHg}$ pada pasien dengan diabetes melittus tipe 2 atau dengan resiko tinggi kardiovaskuler ${ }^{2}$ ) atau pasien dengan tekanan darah terkontrol dalam pengobatan namun dengan pernah memiliki gejala yang dicurigai akibat toleransi buruk pada pengobatan penghambat ACE dan/atau $\mathrm{CCB}$ yang sebelumnya. Pasien dengan diekslusi apabila: mereka berumur kurang dari 18 tahun; memiliki hipersensitivitas atau tidak toleran pada perindopril atau amlodipine; memiliki infak miokard akut atau stroke akut dalam $\leq 3$ bulan; terdiagnosa atau dicurigai memiliki hipertensi sekunder; memiliki penyakit serius yang mempengaruhi prognosis; atau kontraindikasi pada pengobatan (seperti kehamilan dan wanita menyusui).

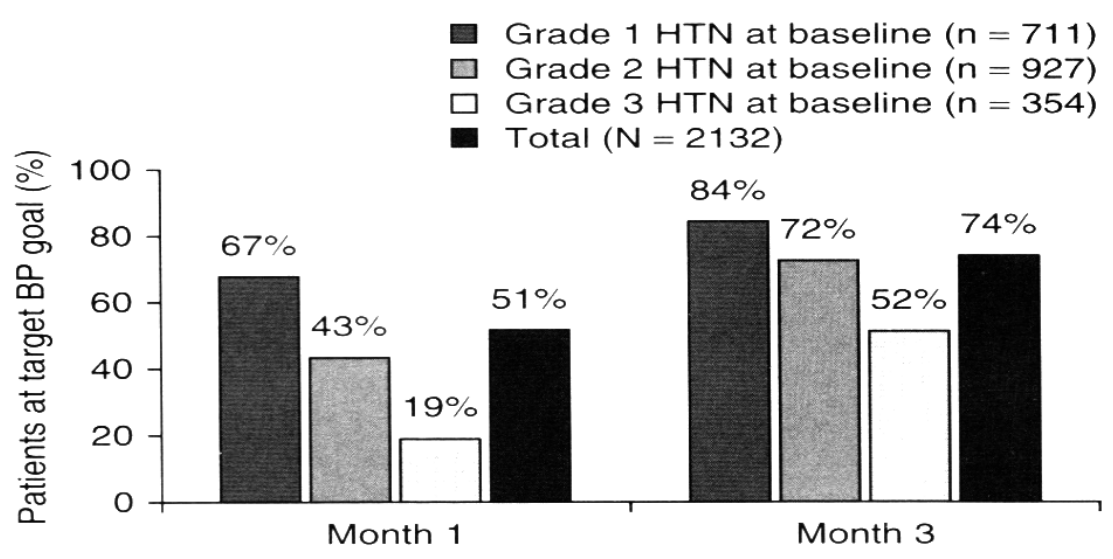

Gambar 2. Persentase pasien yang mencapai tekanan darah target dari waktu ke waktu oleh tingkatan hipertensi. Nilai target dan kelompok berdasarkan keparahan didefiniskan menurut pedoman hipertensi ESC/ESH 2007. ${ }^{[2]}$ Tekanan darah target didefiniskan sebagai TDS/TDS $<140 / 90 \mathrm{mmHg}$ atau $<130 / 80 \mathrm{mmHg}$ pada pasien diabetes mellitus tipe II atau dengan resiko tinggi kardiovaskuler. Analisa dilakukan pada populasi yang ditujukan untuk diobati. Angka sesuai dengan jumlah pasien setiap subgroup pada baseline. Pasien yang mencapai TD target saat baseline $(\mathrm{n}=140)$ tidak digambarkan. $\mathrm{BP}=$ Blood pressure $; \mathrm{DBP}=$ Diastolic $B P ; \mathrm{HTN}=$ Hypertension; $\mathrm{SBP}=$ Systolic BP. 


\section{Keamanan dan tolerabilitas}

Pengobatan dengan FDC perindopril/amlodipine dapat ditoleransi dengan baik. Setelah 3 bulan pengobatan, efek samping yang paling sering terjadi adalah oedema tungkai $(5,4 \%)$, dispneu $(1,8 \%)$, sakit kepala $(1,2 \%)$, batuk (1\%) dan vertigo (1\%). Tidak ditemukan adanya efek samping yang serius.

Jumlah pasien yang menderita oedema tungkai akibat amlodipine menurun dari 163 dari 1085 pasien (15\%) hingga 86 pasien (7,9\%) setelah 1 bulan, pada pengobatan perindopril.

Pada SYMBIO sebuah studi fase IV, longitudinal selama 3 bulan mengenai pengobatan optimisasi dengan FDC perindopril/amlodipine menghasilkan penurunan signifikan secara klinis dan statistik pada tekanan darah pasien dengan insufisiensi kontrol hipertensi dan atau toleransi buruk pada pengobatan sebelumnya dengan $A C E$ inhibitor dan atau CCB. Perubahan secara signifikan pada tekanan darah tercatat tanpa memperhatikan keparahan baseline dan pengobatan baseline. Target tekanan darah dicapai $74 \%$ populasi dari keseluruhan pasien, $84 \%$ pasien dengan hipertensi tingkat 1, dan 52\% pasien dengan hipertensi tingkat 3. Pengobatan cukup bisa ditoleransi dan berhubungan dengan $58 \%$ penurunan jumlah pasien dengan oedema tungkai akibat amlodipin.

Pentingnya kontrol tekanan darah secara berkala untuk kesehatan jantung jangka panjang sudah diketahui dengan baik. Selanjutnya, data dari studi jangka panjang sebelumnya menyimpulkan bahwa keuntungan studi jangka panjang akan dihasilkan dari pengobatan dengan FDC perindopril/amlodipin. Pada percobaan ASCOT-BPLA, ${ }^{7}$ pengobatan 5 tahun dengan amlodipin/perindopril menyebabkan penurunan signifikan secara statistik pada mortalitas kardiovaskular (24\%), stroke (23\%), total kejadian kardiovaskular dan prosedur (16\%), gagal jantung (16\%), kejadian koroner total (13\%), dan kematian akibat semua sebab (11\%) dibandingkan pengobatan atenolol/bendroflumethiazide. Kemudian secara jangka panjang, pasien yang diobati dengan FDC perindopril/amlodipin diharapkan mengalami peningkatan morbiditas kardiovaskular dan mortalitas yang berhubungan dengan penurunan tekanan darah dari efek spesifik perindopril/amlodipin.

Pada studi sekarang, dimana $77 \%$ pasien diobati dengan $A C E$ inhibitor atau kombinasi dengan $\mathrm{CCB}$ sebelum kriteria inklusi, penggantian pengobatan baselineACE inhibitor/amlodipin dengan kombinasi pasti perindopril/amlodipin menyebabkan penurunan signifikan pada tekanan darah. Hasil ini mungkin bisa dijelaskan perbedaan relevan secara klinis pada profil $A C E$ inhibitor yang berbeda. Tentu saja karena $A C E$ inhibitor memiliki farmakokinetik dan farmakodinamik yang berbeda, profil efikasi dan tolerabilitas diharapkan berbeda juga. Contohnya perindopril dimana telah didemonstrasikan efikasi antihipertensinya selama 24 jam dengan pengobatan 1 kali sehari. Dengan rasio menuju puncak $75-100 \%$, perindopril menunujukkan bahwa ia memiliki efikasi 24 jam ketika ditambahkan CCB kerja panjang amlodipin dengan rasio menuju puncak $87 \% .{ }^{19}$

\section{Kesimpulan}

Data dari studi ini mendemostrasikan bahwa pada praktek klinik sehari-hari di Slovakia, perindopril/ amlodipin FDC cukup efektif dan memiliki toleransi baik pada penurunan tekanan darah hingga mencapai target tekanan darah yang direkomendasi pada pasien yang memiliki banyak faktor resiko dan komorbiditas. Meskipun terbukti bahwa keuntungan pada penggunaan amlodipin/perindopril pada pasien hipertensi yang bebas dari penyakit jantung terhadap morbiditas dan mortalitas, ${ }^{18}$ studi tambahan untuk jangka panjang yang spesifik pada FDC perindopril/amlodipin dibutuhkan, untuk menunjukkan penurunan tekanan darah pada studi ini dan disimpukan menjadi penurunan morbiditas kardiovaskular dan peningkatan kelangsungan hidup. Meskipun demikian, data perindopril/amlodipin yang ada disini digabungkan dengan data yang membuat tentang amlodipin dan perindopril menunjukkan bahwa perindopril/amlodipin FDC sangat efektif dan mudah digunakan sebagai pilihan pengobatan jangka panjang untuk hipertensi arterial.

\section{Daftar Pustaka}

1. World Health Organization. Global health risks: mortality and burden of disease attributable to selected major risks. Geneva: WHO Press; 2009

2. Mancia G, De Backer G, Dominiczak A, et al. 2007 Guidelines for the Management of Arterial Hypertension: The Task Force for the Management of Arterial Hypertension of the European Society of Hypertension (ESH) and of the European Society of Cardiology (ESC). J Hypertens 2007 Jun; 25(6): 1105-87 
3. Mancia G, Laurent S, Agabiti-Rosei E, et al. Reappraisal of European guidelines on hypertension management: a European Society of Hypertension Task Force document. J Hypertension 2009 Nov; 27(11): 2121-58

4. Ferrari R. Optimizing the treatment of hypertension and stable coronary artery disease: clinical evidence for fixed-combination perindopril/amlodipine. Curr Med Res Opin 2008 Dec; 24(12): 3543-57

5. Messerli FH. Vasodilatory edema: a common side effect of antihypertensive therapy. Curr Cardiol Rep 2002 Nov; 4(6): 479-82

6. Messerli FH, Weir MR, Neutel JM. Combination therapy of amlodipine/benazepril versus monotherapy of amlodipine in a practicebased setting. Am J Hypertension 2002 Jun; 15(6): 550-6

7. Dahlöf B, Sever PS, Poulter NR, et al. Prevention of cardiovascular events with an antihypertensive regimen of amlodipine adding perindopril as required versus atenolol adding bendroflumethiazide as required, in the Anglo-Scandinavian Cardiac Outcomes Trial-Blood Pressure Lowering Arm (ASCOT-BPLA): a multicenter randomized controlled trial. Lancet 2005 Sep 10-16; 366(9489): 895-906

8. Wang X, Gong L, Guo J, et al. Parallel comparative trial of amlodipine and nitrendipine monotherapy in patients with essential hypertension. J Hypertens Suppl. 1998 Sep; 16(4): S43-7

9. Navarro Estrada JL, Oliveri R. Long-term efficacy of amlodipine in patients with severe coronary artery disease. J Cardiovasc Pharmacol 1993; 22 Suppl. A: S24-8

10. Deanfield JE, Detry JM, Lichtlen PR, et al. Amlodipine reduces transient myocardial ischemia in patients with coronary artery disease: double-blind Circadian Anti-Ischemia Program in Europe (CAPE Trial). J Am Coll Cardiol 1994 Nov 15; 24(6): 1460-7

11. Wang JG, Li Y, Franklin SS, et al. Prevention of stroke and myocardial infarction by amlodipine and angiotensin receptor blockers: a quantitative overview. Hypertension 2007 Jul; 50(1): $181-8$

12. Fox KM. Efficacy of perindopril in reduction of cardiovascular events among patients with stable coronary artery disease: randomised, double-blind, placebo-controlled, multicentre trial (the EUROPA study). Lancet 2003 Sep 6; 362(9386): 782-8

13. PROGRESS Collaborative group. Randomised trial of a perindopril-based blood-pressure-lowering regimen among 6,105 individuals with previous stroke or transient ischaemic attack. Lancet 2001 Sep 29; 358(9287): 1033-41

14. Ferrari R. Effects of angiotensin-converting enzyme inhibition with perindopril on left ventricular remodeling and clinical outcome: results of the randomized Perindopril and Remodeling in Elderly with Acute Myocardial Infarction (PREAMI) Study. Arch Intern Med 2006 Mar 27; 166(6): 659-66

15. Ogilvie RI, Anand S, Roy P, et al. Perindopril for control of blood pressure in patients with hypertension and other cardiovascular risk factors: an open-label, observational, multicenter, general practice-based study. Clinical Drug Investigation 2008; 28(11): 673-86

16. Ceconi C, Fox KM, Remme WJ, et al. ACE inhibition with perindopril and endothelial function. Results of a substudy of the EUROPA study: PERTINENT. Cardiovascular Res 2007 Jan 1; 73(1): 237-46

17. Bahl VK, Jadhav UM, Thacker HP. Management of hypertension with the fixed combination of perindopril and amlodipine in daily clinical practice: results from the STRONG prospective, observational, multicenter study. Am J Cardiovascular Drugs 2009; 9(3): 135-42

18. Weber MA, Julius S, Kjeldsen SE, et al. Blood pressure dependent and independent effects of antihypertensive treatment on clinical events in the VALUE Trial. Lancet 2004 Jun 19; 363(9426): 2049-51

19. Physicians' Desk Reference. Montvale (NJ): Medical Economics Company; 2008 